Dr. Nansen's North Polar Expedition, and Its Scientific Results Author(s): H. Mohn

Source: The Geographical Journal, Vol. 8, No. 4 (Oct., 1896), pp. 389-393

Published by: geographicalj

Stable URL: http://www.jstor.org/stable/1774060

Accessed: 26-06-2016 02:42 UTC

Your use of the JSTOR archive indicates your acceptance of the Terms \& Conditions of Use, available at

http://about.jstor.org/terms

JSTOR is a not-for-profit service that helps scholars, researchers, and students discover, use, and build upon a wide range of content in a trusted digital archive. We use information technology and tools to increase productivity and facilitate new forms of scholarship. For more information about JSTOR, please contact support@jstor.org.

The Royal Geographical Society (with the Institute of British Geographers), Wiley are collaborating with JSTOR to digitize, preserve and extend access to The Geographical Journal 
The most remarkable feature, however, of the Siwalik fauna is the fact that, while certain of the genera are only found in Miocene beds in Europe, and not in more recent deposits, the greater number are only known from the Pliocene and Pleistocene out of India, so that it is very difficult to fix the age of the Siwaliks as compared with the formations of Europe.

Beds containing a somewhat similar fauna, in most cases not so rich, have been discovered in Greece, near Athens, at Samos, and in one or two other localities, at least, in South-Western Europe ; while north of the Alps nothing of the sort has been found of a corresponding age. The most plausible explanation of the whole matter, therefore, so far as we can say at present, is that the increasing cold at the end of the Miocene and the beginning of the Pliocene times gradually drove the northern inhabitants southwards. It thus came to pass that, at that period of the world's history, the mammalian faunas of Southern Europe, South-Eastern Asia, and of India were so nearly uniform as to constitute these countries, as regards their mammals, one widely extended Region.

List OF Literature REFERREd To.

(1) Blanford,W. T.-'The Fauna of British India: Mammalia.' London, 1888-91.

(2) Milne-Edwards, H. ET A.- ' Recherches pour servir à l'histoire naturelle des Mammifères.' Paris, 1868.

(3) Oldham, R. D.- 'Manual of the Geology of India.' Calcutta, 1893.

\section{DR. NANSEN'S NORTH POLAR EXPEDITION, AND ITS SCIENTIFIC RESULTS.*}

\section{By Professor H. MOHN.}

THE object of this expedition was to explore the regions around the North Pole, which had remained quite unknown, on account of the immense difficulties offered to exploration by the physical features, the high latitude, and the severe climate of those parts of our globe. If Fridtjof Nansen has now succeeded in overcoming these difficulties, so as to have crossed a large part of the formerly inaccessible seas round the pole, and has collected such invaluable information and materials for a better knowledge of those latitudes, this was due, first and foremost, to the fact that he is a man of science, who, with his mastery of all that had been done, and the penetration of his genius, could gain an insight into the unknown; and that, with unsurpassed practical sense, he knew how to make the arrangements necessary to secure that his journey, from beginning to end, should be a unique success.

The information about Nansen's journey which we have at our disposal is almost entirely limited to what has come to general knowledge through the press. It is evident that such information contains only the very first rays of the light which will be thrown by the observations of the expedition upon this part of our globe (when they are known in full), but already those first glimpses indicate conclusions of such importance and width, that it will be welcome to the reader to have a preliminary sketch of the scientific results which already have been won by Nansen and his admirable and gallant companions.

As is known, Nansen based the plan of his journey on the assumption that there

* Translated from the Christiania Morgenbladet, September 6, 1896. 
is, to the north of Franz Josef Land, a current which flows from the open sea in the north of the New Siberia islands to the open sea which lies between East Greenland and West Spitzbergen. Some relics from the wrecked Jeannette gave the first hints for suspecting the existence of that current, and its existence was rendered still more probable through the study made by Nansen of different drift products which were found both in Greenland and on Greenland ice in Denmark strait. The Fram had to enter that current, and this it succeeded in doing, and, as was foreseen, the Fram, embedded in ice, was drifted by the current in the direction indicated. That at certain times, especially in summer, the drift would take place in a direction opposed to its general course, was nothing but what could be, and was, foreseen, in consequence of changes in the direction of the winds in the polar sea, the probability of which was indicated by various meteorological considerations. That continuous drift of the Fram for three consecutive years, 1893 to 1896, was thus a considerable triumph for meteorology, and not a small one for oceanography. The ice, under the influence of the prevailing winds, is in continuous drift, and the conception of a fast ice-sheet covering the polar sea has thus now to be abandoned.

During that drift the North Polar expedition made its greatest discovery, namely, a wide deep sea towards the North Pole, having a relatively warm temperature in its depths. From what was known through previous expeditionsthe voyages of the Vega and the Jeannette, as well as the British and American polar expeditions-it was supposed that the North Polar sea is a shallow basin which has ice-cold water in its depths, and is always covered with floating ice. The journey of the Fram has astonished the world by its discovery of quite different conditions. From the open sea which lies on the north-west of the New Siberian islands, the sea-bottom sinks deeper and deeper towards the north and west, and we thus have a deep sea-basin which, by its depths attaining as much as 2000 fathoms, appears to be a continuation of our own polar sea, situated between Greenland on the one side, and Norway and Spitzbergen on the other side. Some soundings made in the later part of the journey of the Fram, on the north of Spitzbergen, show that the circumpolar basin is continued without interruption in the European polar sea, which was found by the Norwegian North Atlantic expedition to have a depth of more than 2000 fathoms on the south-east of Jan Mayen; and by Nordensjolld's Sophia expedition, to have a depth of 2650 fathoms halfway between Greenland and Spitzbergen, and of 1370 fathoms on the north of Spitzbergen.

The depths which were found north of Franz Josef Land and Spitsbergen, in connection with the disappearance of animal life, as also the structure of ice, which were noticed both by Nansen and the Fram as they reached their highest latitudes, unavoidably bring us to the supposition that in all probability the sea round the North Pole is a deep sea, covered all the year round with a tightly packed drifting ice.

The distribution of temperature in that circumpolar ice-sea is, however, most remarkable. The upper layer, down to a depth of about 100 fathoms, was found to be everywhere below the freezing-point, the temperature being in places as low as : half a degree Centigrade below zero (i.e. between $32^{\circ}$ and $31^{\circ}$ Fahrenheit, and occasionally as low as $31 \cdot 1^{\circ}$ ); that is, a temperature which the North Atlantic expedition found to prevail over most of our North Polar sea (or North Atlantic) in its deepest layers. But in the circumpolar sea, Nansen's expedition found, below the 100 fathoms' level, a temperature above the freezing-point, also by about half a degree (i.e. nine-tenths of a Fahrenheit degree), and, so far as may be gathered from the available information, this temperature extends to the very bottom. 
However, on the north of Spitzbergen, that passage from temperatures below the freezing-point to temperatures above it took place at a depth of 500 fathoms, and the warmer temperature was maintained to the bottom.

The unexpected discovery of a deep sea, containing water whose temperature is above the freezing-point, in the vicinity of the North Pole, promises to explain a great deal of the life of the globe in a quite different way from what has hitherto been considered as the right explanation. And, by the way, it is worth noticing that just as Nansen's greatest discovery in Greenland-namely, that its interior contains one of the poles of cold of the Earth-was made notwithstanding that his thermometers were not able to show the lowest degrees of cold, so also the sounding apparatus taken on the Fram was far from being able to measure depths of 2000 fathoms. But Nansen is the man to create means where there were none, and the sounding apparatus which was made proved to be of the most modern sort; it was made out of iron wire taken from an iron cable.

So far as we can judge for the moment, the only way in which warm water can enter the North Polar basin is that it should come from the current of warm water which the North Atlantic expedition found, in 1878, off the western coast of Spitzbergen. There we have warn water, originating in the warm current of the North Atlantic-the Gulf Stream taken in its widest sense-which has ice-cold water beneath it, and runs over the banks of Spitzbergen northwards towards the sea on the north of Spitzbergen, which was explored by the Fram during the last days of its drift with the ice, from which it seems to run further north and east into the circumpolar basin. That in its upper layer this sea is covered with ice, and has a temperature below the freezing point, depends of course upon the length of the winter, but also upon the smaller salinity of the upper layer. One need only think of the masses of fresh water which are poured into that basin by the great rivers of Siberia and Arctic America. The water of the Gulf Stream, being salt, on the contrary, has a greater density when it cools down, and the fresh water remains in the upper layers; it may also, on account of its greater density, flow to the deepest parts of the sea. But that its temperature does not sink below zero is one of the most wonderful phenomena which a North Polar expedition could have discovered.

The numerous and accurate observations on the direction and force of the wind, of the currents and drift of ice on the sea surface, of the temperature and salinity of water at different depths, which were carried on on board the Fram all the time, will furnish invaluable material for the study of the mechanism of oceanic currents. We have already a direct connection between the results obtained through the study of the North Atlantic currents by the Norwegian North Atlantic expedition, and those of Nansen's expedition, which are a most brilliant further development of the former. We have, moreover, the pleasure to mention that the Danish East Greenland expedition, on board the Hekla, under Captain Ryder, has also noticed on the Greenland banks the presence of warm water beneath the cold-a fact which is of the greatest importance for understanding the conditions which were found by the Fram. And we are also sure to obtain more information for the comprehension of the North Atlantic currents from the just-returned Danish Ingolf expedition, under Commander Wandel.

When we think, at the same time, of what we have lately learned about the influence exercised by the sea-currents of the polar sea and the distribution of temperature over its surface upon the weather in Northern Europe, and especially in Norway and Sweden, we are entitled to expect from all these sides such new data as cannot but improve our present system of weather forecasts, and thus will have a substantial economical importance. 
This brings us to consider the importance of Nansen's North polar expedition for meteorology. The members of that expedition, provided with the very best meteorological instruments, have uninterruptedly made meteorological observations. For three years the Fram was in this way a first-class meteorological station, at which, besides the reading of the usual instruments, self-registering apparatus recorded at every moment the pressure of the air and the temperature. All instruments were continually verified and compared with the standard instruments. We need hardly, therefore, insist upon the importance which the three years' work of a standard meteorological station, situated within 4 to 5 degrees from the pole, will undoubtedly have in extending our knowledge of the conditions of the atmosphere, both in those regions and elsewhere. We can already trace the influence of the relatively warm deep sea in the fact that the lowest temperature observed on the Fram was $-52^{\circ}$ Celsius $\left(-61.5^{\circ} \mathrm{Fahr}\right.$.), while in the Kara sea we find already $-53^{\circ}\left(-63^{\circ}\right.$ Fahr.), and at the Russian station at the mouth of the Lena $-70^{\circ}$ Celsius ( $-94^{\circ}$ Fahr.) was observed.

For both the meteorologist and the hydrographer, the sledge-journey of Nansen and Johansen and their wintering are of the greatost importance. They have ascertained that between Franz Josef Land and the latitude of $86^{\circ} 14^{\prime}$ there is a sea, mostly covered, of course, with ice, but no land. And during the whole of that journey they have continued to make meteorological observations, just as Nansen made them on the Greenland ice-cap.

For the interval of time from March, 1895, till the summer of 1896, meteorologists will thus be enabled to construct daily weather charts embodying the observations of the Fram, of Nansen and Johansen, of Jackson on Franz Josef Land, and of Ekroll in East Spitzbergen, which charts will represent a quite unique development of polar studies. It will be most interesting to see if it be possible to find any connection between the weather in that part of the polar regions and the weather which we have had at the same time. We have had both a cold and a mild winter during these two years.

A series of researches, whose chief interest is for pure science, but which also have a certain practical bearing, were carried on on board the Fram concerning the magnetism of the Earth. Most perfect instruments, which had been made for that special purpose, had been taken by the expedition. It is the venerable director of the "Deutsche Seewarte," in Hamburg, Prof. Dr. G. Neumayer, to whom the expedition owes its thanks for having been provided with such instruments, and in the able hands of Lieut. Scott Hansen they were continually in use. The calculation of the magnetical observations which were made at the international circumpolar stations during the years 1882-83 has shown that our knowledge of the Earth's magnetism is utterly incomplete, and that observations in both the North and South Polar regions are badly wanted. Now, the observations on board the Fram will fill up, at least, one of these gaps. They are looked forward to by physicists with the greatest interest.

Moreover, it is known that with the introduction of iron ships, the use of the compass becomes much more difficult than it formerly was on wooden ships. In order to be able to use the compass on board an iron ship, we must know the distribution of magnetism on the Earth's surface, and its variations from spot to spot, and in time as well. These variations must be calculated by the navigator in advance; but to do that, we must be in possession of the most exact knowledge of the laws of terrestrial magnetism. The observations on board the Fram will accordingly be of the greatest value for both science and practice.

In connection with the above, we may mention the numerous observations of auroræ, which were made on board the Fram by Dr. Blessing, who also took an active part in the deep-sea observations and everything relating to them. 
We are also happy to say that the astronomical observations which were made on board the Fram, as well as during the sledge journey of Nansen and Johansen, for the determination of latitudes and longitudes, were mostly made with the instruments prepared at Christiania, by the instrument-maker, C. H. G. Olsen, who has also constructed the Mohn anemometer, with which the velocity of the wind was measured at the regulation hours.

Of purely geographical results, we may name the discovery of the new island in the northern part of the Kara sea, and of several new islands off the coast of Siberia. Payer's map of the northern part of Franz Josef Land was found by Nansen quite misleading. It will be Jackson's work to give us a new map of that archipelago.

Nansen has also made some geological observations on the north coast of Siberia, which bear testimony to its having been under an ice-sheet, while it was formerly maintained that Siberia had not undergone glaciation.* The observations upon the life of animals and plants evidently could not be many or of striking importance, on account of the very character of the regions which were explored. But it is not implied by this-the contrary being far more probable-that a biologist like Dr. Nansen should not have bad opportunities for making such observations as are sure to throw an interesting light upon the conditions of organic life in the polar seas and on the deserts of the polar ice.

And, finally, there is one result, of the highest scientific interest, which must be mentioned, and which we. owe to Dr. Nansen. He has found out, and proved the advisability of, new methcds for journeys through the wilderness of the North Polar seas. First of all, we must mention the design of the Fram, which he invented, and which was so successful that the ship proved in all respects to be what Nansen's experience, forethought, and practical sense expected it to be. Nansen has next foretold and shown what may be achieved with dog-sledges and kayaks for progress over the polar sea, with all its even and uneven surfaces of ice, and its open spaces between the ice and near the islands. And he has proved that it is possible for men to maintain life and energy enough to be able to do scientific work, by adopting a mode of life which corresponds to that indicated by Nature itself to the Eskimo inhabitants of those northern parts of the Earth. Of course, this life necessitates such men as Nansen and bis comrades.

It is also most remarkable to learn how all the members of the expedition kept well, and fit for work, during the whole duration of the expedition. This is a brilliant proof of the excellent way in which Nansen, aided by the best scientific advice, organized his expedition.

It will take not a little time before the observations made during Dr. Nansen's expedition can be published, after having been worked out in a scientific way, so as to be ready to be taken in connection with other observations of the same kind. The work which will contain all these results will be a shining light in science, and we shall have the joy of knowing that that light shines from our mothercountry, and that it is due to one of its most gallant sons, Fridtjof Nansen.

* Baron Toll's observations had already been to the same effect.-Note by the translator. 